Gut, 1978, 19, 886-891

\title{
Availability of monoglutamyl and polyglutamyl folates in normal subjects and in patients with coeliac sprue
}

\author{
C. H. HALSTED ${ }^{1}$, A. M. REISENAUER, B. SHANE, AND T. TAMURA
}

From the Department of Internal Medicine, University of California, Davis, California, and Department of Nutritional Sciences, University of California, Berkeley, California, USA

SUMMARY Intestinal folate absorption was assessed in six normal subjects and in four patients with coeliac sprue who were studied before and after treatment by dietary gluten exclusion. Comparisons were made of the luminal disappearance from the perfused jejunum of ${ }^{3} \mathrm{H}$-pteroylmonoglutamate and pteroyl ${ }^{14} \mathrm{C}$-glutamylhexaglutamate, and of the 48-hour urinary recovery of each isotope after perfusion and a tissue saturating dose of folic acid. The labelled urinary folates consisted of folic acid, 10-formyltetrahydrofolate, and 5-methyltetrahydrofolate. In each group urinary recovery of ${ }^{3} \mathrm{H}$ was significantly greater than that of ${ }^{14} \mathrm{C}$, confirming the evidence from jejunal perfusion that the availability of monoglutamyl folate is greater than that of polyglutamyl folate. According to the urinary recovery data, both folates were poorly absorbed in untreated coeliac sprue, but were normally absorbed after treatment. Assuming uniform displacement of the absorbed labelled folates by the parenteral flushing dose, the finding of greater urinary isotope recovery than of luminal folate disappearance from the perfused proximal jejunal segment suggests an adaptation of the distal small bowel for folate absorption in coeliac sprue.

The nearly universal finding of folate deficiency in adult patients with untreated coeliac sprue (Weir, 1974) reflects the fact that the proximal small intestine, the optimal site of absorption of folic acid (Hepner et al., 1968; Halsted et al., 1971), is most severely affected in this mucosal disease. Dietary folates are a mixture of pteroylpolyglutamates (Butterworth et al., 1963) which, during the process of intestinal absorption, are hydrolysed to pteroylmonoglutamate (PteGlu) by an intestinal mucosal $\gamma$-carboxypeptidase known as folate conjugase (Rosenberg et al., 1969; Butterworth et al., 1969; Baugh et al., 1971; Halsted et al., 1975). Using the technique of jejunal perfusion of separately labelled ${ }^{3} \mathrm{H}$-pteroylmonoglutamate $\left({ }^{3} \mathrm{H}-\mathrm{PteGlu}\right)$ and pteroyl ${ }^{14} \mathrm{C}$-glutamylhexaglutamate $\left({ }^{14} \mathrm{C}-\mathrm{PteGlu}{ }_{7}\right)$, we recently described extreme malabsorption of both compounds in untreated coeliac sprue (Halsted et al., 1977).

\footnotetext{
${ }^{1}$ Address for reprint requests: $\mathrm{Dr} \mathrm{C}$. H. Halsted, Section of Gastroenterology, TB 192, School of Medicine, University of California, Davis, California, 95616, USA.

Received for publication 19 April 1978
}

Assessment of small intestinal function from data obtained by jejunal perfusion is limited to the perfused intestinal segment, and thus may overlook adaptive responses in the more distal bowel. Previous studies have likened coeliac sprue to a jejunal resection, in that increased intestinal uptake of glucose and electrolytes could be demonstrated in the perfused ileum of certain patients (Silk et al., 1975). A previous perfusion study in man showed that the normal intestinal uptake of PteGlu decreased as more distal segments were tested, whereas the uptake of PteGlu from the upper and lower jejunum was similar in four patients with coeliac sprue (Hepner et al., 1968). Providing that the absorbed labelled folate is uniformly displaced from the tissues by a flushing dose of parenteral folic acid, measurement of urinary isotope recovery can be used as an index of total intestinal folate absorption. In the present report, comparisons are made of folate absorption assessed by the two methods of jejunal perfusion and of urinary isotope recovery in normal subjects and in patients with coeliac sprue. The data suggest that the lower small intestine adapts to decreased jejunal folate absorption in coeliac sprue. 
The urinary folate excretion data confirm our previous evidence (Halsted et al., 1977) that ${ }^{3} \mathrm{H}-\mathrm{PteGlu}$ is more available than ${ }^{14} \mathrm{C}-\mathrm{PteGlu} 7$ in health and in mucosal disease.

\section{Methods}

\section{PATIENTS}

Urinary isotope recovery was measured after jejunal folate perfusion in six normal adult male volunteers and in four adult patients with coeliac sprue who were studied both in exacerbation and in partial remission. These subjects were included in the larger groups from which jejunal perfusion data have previously been reported (Halsted et al., 1977). The normal volunteers were hospital or professional personnel, aged 28 to 53 years. The patients with coeliac sprue included two men and two women aged 43 to 58 years, each of whom had suffered from diarrhoea for more than a 20 year period, with associated weight loss or inability to gain weight. Three of the patients were studied before treatment, and again after a six to eight week period of glutenfree diet. The fourth patient was initially studied while in remission and again after 10 days of gluten challenge (two slices of whole wheat bread per day). Laboratory findings before treatment or after gluten challenge included low d-xylose absorption (Roe and Rice, 1948) (five-hour urinary excretion of $1.8 \mathrm{~g}$ to $3.5 \mathrm{~g}$ after an oral dose of $25 \mathrm{~g}$; normal more than $4.5 \mathrm{~g}$ ) steatorrhoea (Van de Kamer et al., 1949) $(25.3 \mathrm{~g}$ to $48.0 \mathrm{~g}$ faecal lipid per day; normal less than $7 \mathrm{~g}$ ), and a typical flat jejunal mucosal specimen obtained by Crosby capsule biopsy. In remission, every jejunal mucosal biopsy showed partial villous atrophy, while five-hour d-xylose excretion $(3.3$ to $5.6 \mathrm{~g}$ ) and faecal lipid excretion $(8.4$ to $14.0 \mathrm{~g} /$ day) had improved in each case, with weight gain and decreased stool frequency.

As previously described (Halsted et al., 1975), folate absorption was studied using two separately labelled compounds, ${ }^{3} \mathrm{H}-\mathrm{PteGlu}\left(3^{\prime} 5^{\prime} 9{ }^{3} \mathrm{H}\right]-$ folic acid, Amersham/Searle) and ${ }^{14} \mathrm{C}-\mathrm{PteGlu}$. The latter compound was synthesised by the solid phase method (Krumdieck and Baugh, 1969), so that the ${ }^{14} \mathrm{C}$ label was on the first glutamyl unit (provided by Professor C. L. Krumdieck, University of Alabama) and hence remained in the folic acid molecule after hydrolysis. One litre jejunal perfusion solutions of isotonic saline were prepared containing $4 \mu \mathrm{C}$ $(2 \mu \mathrm{mol})$ of ${ }^{3} \mathrm{H}-\mathrm{PteGlu}$ and $2 \mu \mathrm{C}(2 \mu \mathrm{mol})$ of ${ }^{14} \mathrm{C}$ PteGlu $_{7}$. The solutions were perfused at a site $10 \mathrm{~cm}$ distal to the ligament of Treitz at a rate of $10 \mathrm{ml} / \mathrm{min}$. After a 45 minute period of equilibration, samples were collected at a rate of $1 \mathrm{ml} / \mathrm{min}$ from a site $30 \mathrm{~cm}$ downstream. On completion of the perfusion, each subject received an intramuscular, tissue-saturating 'flushing' injection of folic acid (Folvite, Lederle Laboratories, Pearl River, NY), $34 \mu \mathrm{mol}(15 \mathrm{mg})$. The jejunal perfusion tube was then withdrawn and urine was collected for the next 48 hours for measurement of isotope recovery. The collections were made in four consecutive 12 hour periods. Maximal isotope recovery occurred in the first 12 hour periods, with less than $5 \%$ of the total recovery in the last 12 hour periods. Isotope counting was performed on a Beckman LS 260 liquid scintillation counter, with efficiencies of $29 \cdot 2 \%\left({ }^{3} \mathrm{H}\right)$ and $62.0 \%$ $\left({ }^{14} \mathrm{C}\right)$. One 12 hour urine collection from a normal subject was made in the presence of $17 \mathrm{mmol}(3 \mathrm{~g})$ of ascorbic acid and then stored at $-70^{\circ} \mathrm{C}$. Subsequently, $10 \mathrm{ml}$ of this collection were diluted with $200 \mathrm{mmol} / 1 \beta$-mercaptoethanol to a volume of $250 \mathrm{ml}$. The mixture (pH 6.4) was then applied to a DEAE-cellulose column, $20 \times 1 \mathrm{~cm}$, and folates were eluted by a gradient constructed from $100 \mathrm{ml}$ of phosphate buffer, $5 \mathrm{mmol} / \mathrm{l}$, in a closed mixing chamber, attached to a reservoir of phosphate buffer, $500 \mathrm{mmol} / \mathrm{l}$. The buffers were $\mathrm{pH} 6$ and contained $200 \mathrm{mmol} / 1 \beta$-mercaptoethanol. Fractions were counted for radioactivity and assayed for folate activity using Lactobacillus casei and Streptococcus faecalis (Tamura et al., 1972). The identity of each peak was verified by chromatographing a separate urine sample with a variety of unlabelled and ${ }^{3} \mathrm{H}$-labelled authentic folate standards (Shane and Stokstad, 1976).

Previously described formulas (Halsted et al., 1975) were used to calculate luminal disappearances of each labelled folate $(\% / 30 \mathrm{~cm}$ of perfused jejunal segment). Urinary recovery of each labelled folate in 48 hours was calculated as a percentage of that perfused. In expressing the relationship between luminal disappearance and urinary recovery, linear regression lines were computed by the method of least squares with a calculation for variance (Steele and Torrie, 1960), In this analysis, the absorption of ${ }^{14} \mathrm{C}-\mathrm{PteGlu} 7$ was considered on the same slope as that of ${ }^{3} \mathrm{H}-\mathrm{PteG}$ lu, since present evidence indicates that ${ }^{14} \mathrm{C}-\mathrm{PteGlu}$, produced by prior intestinal hydrolysis, is the form in which perfused ${ }^{14} \mathrm{C}-\mathrm{PteGlu} 7$ is absorbed (Halsted et al., 1977: Dhar et al, 1977). The relationship between luminal disappearance and urinary recovery in coeliac sprue was compared in patients studied both before treatment, with flat jejunal biopsies, and in the same patients in early remission whose jejunal biopsies showed partial villous atrophy. The paired $t$ test was used to compare results of absorption of each folate within each group, while the unpaired $t$ test was used to compare results among the groups. 
Results

Figure 1 depicts the 48 hour urinary recovery of ${ }^{3} \mathrm{H}$ and ${ }^{14} \mathrm{C}$. In the normal group, and in each coeliac sprue group, the urinary recovery of ${ }^{3} \mathrm{H}$ was significantly greater than that of ${ }^{14} \mathrm{C}(\mathrm{P}<0.001$ in each group). The recovery of each folate in the untreated coeliac sprue group was significantly less than that in the normal group $(\mathrm{P}<0.01, \mathrm{P}<0.01)$, whereas recovery of each folate in the treated group was similar to that in the normal subjects.

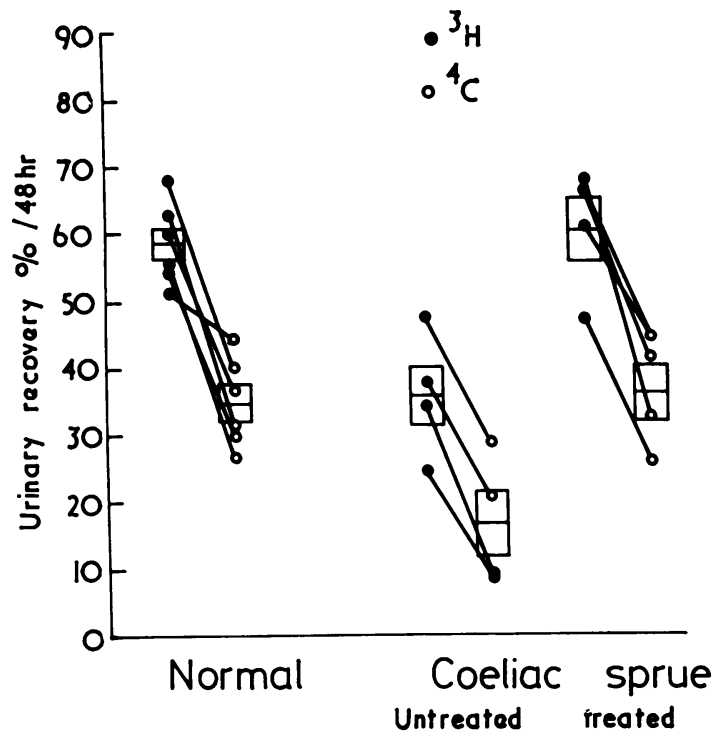

Fig. 1 Recovery of ${ }^{3} \mathrm{H}$ and ${ }^{14} \mathrm{C}$ in urine collected for 48 hours after jejunal perfusion of ${ }^{3} \mathrm{H}$-PteGlu and ${ }^{14} \mathrm{C}$ PteGlu, 2 umol each, in normal subjects and in patients with coeliac sprue studied before and after treatment by dietary gluten exclusion. Each perfusion was followed by a flushing dose of folic acid, 34 umol. Lines connect studies in the same individual and mean $\pm S E M$ is shown by the bars in boxes. Urinary recovery of ${ }^{3} \mathrm{H}$ was significantly greater than that of ${ }^{14} \mathrm{C}$ $(\mathrm{P}<0.001)$ within each group. Isotope recoveries in untreated sprue were significantly less than in the control group $(\mathrm{P}<0.01,0.01)$ while recoveries in the treated group were normal.

Figure 2 shows the elution profile of labelled folates in a 12 hour urine collection from a normal subject. All the recovered radioactivity appeared as folate monoglutamate derivatives. By use of differential growth of the two test organisms and unambiguous marker folates, the major peak (IV) was identified as folic acid. Within this peak, ${ }^{3} \mathrm{H}-\mathrm{PteGlu}$ and ${ }^{14} \mathrm{C}$-PteGlu appeared in an DPM ratio of $3 \cdot 9: 1$, which is approximately the product of the ratio of administered radioactivity of ${ }^{3} \mathrm{H}-\mathrm{PteGlu}$

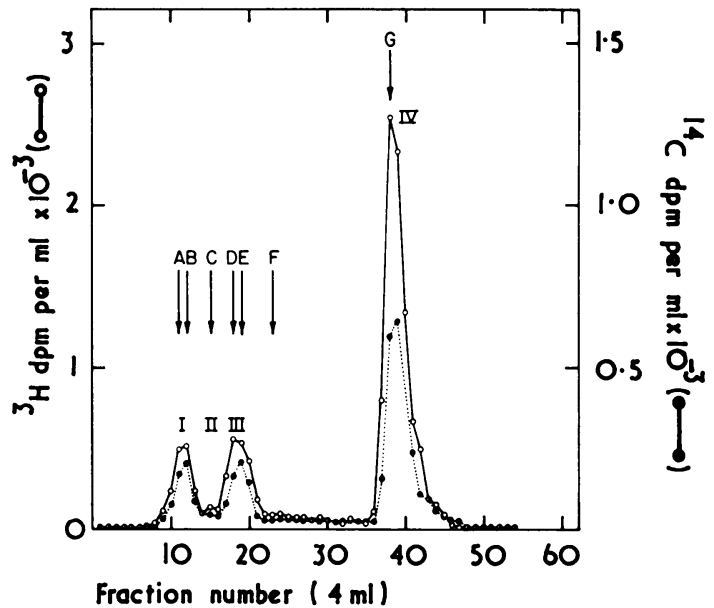

Fig. $2 D E A E$ cellulose elution profile of labelled folate derivatives in urine. The elution positions of authentic folate standards, chromatographed under identical conditions and indicated by the arrows, are: A: 10-formyltetrahydrofolate; $B:\left({ }^{3} \mathrm{H}\right)$ p-aminobenzoylglutamate; $C$ : 10-formylfolic acid; D: 5-formyltetrahydrofolate; E: 5-methyltetrahydro- $\left({ }^{3} \mathrm{H}\right)$-folate; $F$ : tetrahydro- $\left({ }^{3} \mathrm{H}\right)$-folate, and $G$ : folic acid.

and ${ }^{14} \mathrm{C}-\mathrm{PteGlu}_{7}$ (2 to 1 ) and of mean urinary recovery of each label in the control group (59 to 34, Fig. 1). Lesser radioactivity peaks (I and III) were identified as 10-formyltetrahydrofolate and 5-methyltetrahydrofolate. The presence of a small amount of labelled p-amino-benzoylglutamate was suggested by the slight skewing of the microbiological activity profile to the left of the radioactive peak I. Although the marker for 5-formyltetrahydrofolate appeared within peak III, the absence of activity for $S$. faecalis in this peak identified it as 5-methyltetrahydrofolate. A minor peak (II) eluted at the position of 10 -formylfolic acid.

Figure 3 shows the linear relationships between luminal disappearance of folates and urinary isotope recovery in the control group and in the coeliac sprue patients studied before and after treatment. In the control group, the slope of the linear regression of $1.23 \pm 0.27$ indicated somewhat less than complete urinary recovery of radioactivity after absorption from the perfused jejunal segment. On the other hand, the finding of slopes less than 1.0 in each coeliac group, each significantly less than the slope of the control group $(\mathrm{P}<0.05, \mathrm{P}<0.005)$, suggested greater folate absorption, and hence urinary isotope recovery, from the more distal small bowel than from the perfused jejunal segment in these patients. 


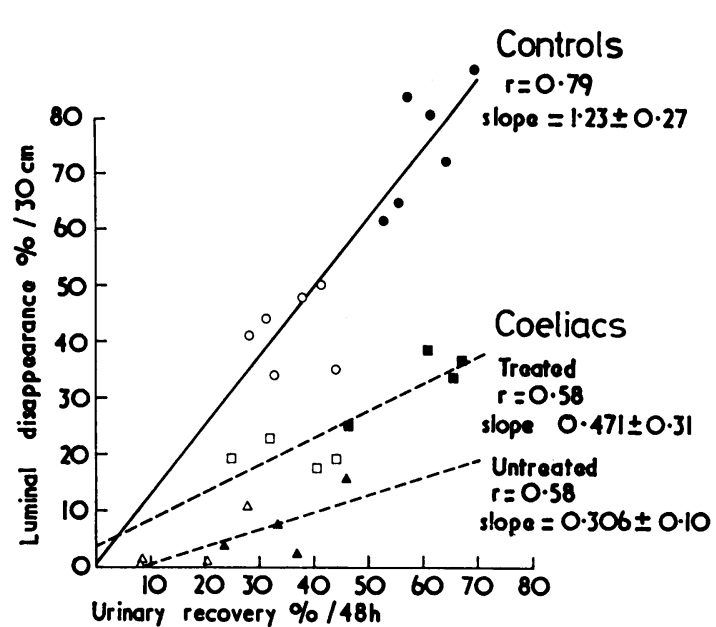

Fig. 3 Linear regression analysis of luminal disappearance of ${ }^{3} \mathrm{H}$-PteGlu and ${ }^{14} \mathrm{C}-\mathrm{PteGlu} \mathrm{H}_{7}(\% / 30 \mathrm{~cm}$ perfused jejunal segment) and 48 hour urinary isotope recovery of ${ }^{3} \mathrm{H}$ and ${ }^{14} \mathrm{C}$ (percentage of administered amount). Closed symbols represent ${ }^{3} \mathrm{H}$ compounds and open symbols represent ${ }^{14} \mathrm{C}$ compounds. Each point represents a single study. The slope for the control group was significantly greater than the slopes obtained for each coeliac sprue group ( $\mathrm{P}<0.05$, $<0.005)$.

\section{Discussion}

Previous studies, using oral doses and measurements of serum levels and of urinary excretion, described malabsorption of PteGlu in the majority of patients with untreated coeliac sprue (Anderson et al., 1960; Cooke et al., 1963; Stewart et al., 1967; Freedman et al., 1973). Hoffbrand et al. (1970) used microbiological serum folate assays in finding equally poor absorption of folic acid and conjugated folate in their coeliac sprue patients. On the other hand, using the method of jejunal perfusion of separately labelled monoglutamyl and polyglutamyl folates, we recently showed marked impairment of absorption of both folate forms in patients with untreated coeliac sprue, with incomplete recovery of jejunal luminal folate disappearance after clinical remission (Halsted et al., 1977). In the present analysis, folate absorption was measured by urinary isotope recovery in order to assess absorption from the entire intestine rather than just from the perfused jejunal segment. The data shown in Fig. 1 confirm the finding of impaired absorption of both monoglutamyl and polyglutamyl folate in untreated coeliac sprue, but show that, with treatment, correction of intestinal folate absorption is more rapid than previously suggested (Halsted et al., 1977).
Analysis of folate absorption from measurement of recovery of urinary radioactivity supposes that all the excreted labelled compounds are folate derivatives. As demonstrated in Fig. 2, each label was excreted as a mixture of intact folates, the majority as ${ }^{3} \mathrm{H}-\mathrm{PteGlu}$ and ${ }^{14} \mathrm{C}$-PteGlu. Identical ${ }^{3} \mathrm{H}$ and ${ }^{14} \mathrm{C}$ labelling of these compounds is consistent with previous evidence that ${ }^{14} \mathrm{C}-\mathrm{PteGlu}_{7}$ is absorbed as its hydrolytic product ${ }^{14} \mathrm{C}$-PteGlu, and hence enters the same metabolic pool as ${ }^{3} \mathrm{H}-\mathrm{PteGlu}$ (Rosenberg, 1976; Halsted et al., 1977). Apart from unmetabolised folic acid, the major folate metabolites in the urine were 10-formyltetrahydrofolate and 5-methyltetrahydrofolate. Others have described both these forms in the urine of scorbutic patients (Stokes et al., 1975) and 5-methyltetrahydrofolate as the major urinary folate in normal subjects given flushing doses of parenteral folic acid (Chanarin and McLean, 1967; Godwin and Rosenberg, 1975).

The present study of folate absorption measured by urinary isotope excretion confirms our previous observations from jejunal perfusion studies that the availability of ${ }^{3} \mathrm{H}-\mathrm{PteGlu}$ is significantly greater than that of ${ }^{14} \mathrm{C}-\mathrm{PteGlu}_{7}$, in normal subjects and in patients with coeliac sprue (Halsted et al., 1975, 1977). These data agree with those of Godwin and Rosenberg (1975) who described in normal subjects significantly greater mean urinary isotope excretion after oral ${ }^{3} \mathbf{H}$-PteGlu than that after oral ${ }^{3} \mathrm{H}-\mathrm{PteGlu}$, each dose followed by a $34 \mu \mathrm{mol}$ ( $15 \mathrm{mg}$ ) flushing dose of folic acid. The present technique has the advantage of the simultaneous administration of both folates, hence avoiding potential variations which may occur with sequential testing. By measuring changes in serum and urine levels after sequential oral doses and the haematological response to each folate form, Perry and Chanarin (1968) also described significantly greater availability of monoglutamyl than of polyglutamyl folate in normal subjects and in patients with megaloblastic anaemia. These findings contrast with those of Tamura and Stokstad (1973) who described similar folate levels in urine after the administration of oral doses of synthetic PteGlu and PteGlu 7 to normal volunteers in a steady state of folate saturation.

The present comparisons of urinary isotope recovery could reflect differences in experimental conditions between the groups, since, at the time of the flushing dose of parenteral folic acid immediately following perfusion, a greater proportion of labelled folate had been absorbed in the control group than in the patients with coeliac sprue. Several different studies have evaluated the effect of the flushing dose on tissue displacement of orally administered labelled folates. Calculations based on the change in serum levels and urinary excretion of folate one hour 
after intravenous PteGlu, $68 \mu \mathrm{mol}$, suggested that the amount of folate taken up by the tissues was within the estimated range of total body stores (Halsted et al., 1967). Freedman et al. (1973) found reproducible daily urine excretion of radioactivity when normal subjects were tested each day for five days with oral ${ }^{3} \mathrm{H}-\mathrm{PteGlu}$ followed immediately each time by a parenteral flushing dose of $34 \mu \mathrm{mol}$. Two additional studies demonstrated that, within limits, the timing of the flushing dose is not critical to subsequent recovery of urinary isotope. Anderson et al. (1960) showed that the urinary excretion of radioactivity in normal subjects was not affected by varying the time of the parenteral flushing injection of $34 \mu \mathrm{mol}$ from two hours before to two hours after the oral administration of ${ }^{3} \mathrm{H}-\mathrm{PteGlu}$. In the studies of Godwin and Rosenberg (1975) urine isotope recovery was similar whether the tissue saturating dose of $34 \mu \mathrm{mol}$ was administered 24 hours before or four hours after oral labelled ${ }^{3} \mathrm{H}-\mathrm{PteGlu}$ or ${ }^{3} \mathrm{H}$ PteGlu 7 . These observations support the implicit assumption in the present study that, although the folates were absorbed at different rates, the flushing dose resulted in uniform displacement of the labels from the tissues.

A study of ileal mucosal histology and assessment of vitamin $B_{12}$ absorption indicated that the ileum is usually spared in coeliac sprue (Stewart et al., 1967). Subsequent perfusion studies showed heightened uptake from the ileum of perfused glucose, water, and electrolytes (Silk et al., 1975) and loss of the normal decreasing gradient for folic acid absorption between upper and lower jejunum in certain patients with coeliac sprue (Hepner et al., 1968). The present data comparing jejunal uptake and urinary isotope recovery suggest a distal intestinal adaptive response for absorption of both PteGlu and PteGlu in coeliac sprue. In the absence of such a response, urinary isotope recovery should be less than the measured luminal disappearance, as occurred in the control group (Fig. 3). The patients with coeliac sprue exhibited the opposite finding of greater urinary isotope recovery than of luminal folate disappearance. Since the ileum is normally a poor site of absorption for PteGlu, these studies suggest functional hypertrophy-that is, adaptation-of folate absorption in the distal bowel of patients with coeliac sprue.

This work was supported by Grants AM 18330 and AM 08171 from the National Institutes of Health, Bethesda, Maryland, USA. The authors are indebted to Professor C. L. Krumdieck for provision of the ${ }^{14} \mathrm{C}$ labelled folates used in these studies.

\section{References}

Anderson, B., Belcher, E. H., Chanarin, I., and Mollin, D. L. (1960). The urinary and faecal excretion of radioactivity after oral doses of ${ }^{3} \mathrm{H}$-folic acid. British Journal of Haematology, 6, 439-455.

Baugh, C. M., Krumdieck, C. L., Baker, H. J., and Butterworth, C. E., Jr (1971). Studies on the absorption and metabolism of folic acid. Folate absorption in the dog after exposure of isolated intestinal segments to synthetic pteroylpolyglutamates of various chain lengths. Journal of Clinical Investigation, 50, 2009-2021.

Butterworth, C. E., Jr, Baugh, C. M., and Krumdieck, C. L. (1969). A study of folate absorption and metabolism in man utilizing carbon-14-labeled polyglutamates synthesized by the solid phase method. Journal of Clinical Investigation, 48, 1131-1142.

Butterworth, C. E., Jr, Santini, R., Jr., and Frommeyer, W. B., Jr (1963). The pteroylglutamate components of American diets as determined by chromatographic fractionation. Journal of Clinical Investigation, 42, 19291939.

Chanarin, I., and McLean, A. (1967). Origin of serum and urinary methyltetrahydrofolate in man. Clinical Science, 32, 57-67.

Cooke, W. T., Fone, D. J., Cox, E. V., Meynell, M. J., and Gaddie, R. (1963). Adult coeliac disease. Gut, 4, 279-291.

Dhar, G. J., Selhub, J., Gay, C., and Rosenberg, I. H. (1977). Direct in vivo demonstration of the sequence of events in intestinal polyglutamyl folate absorption. Clinical Research, 25, 309A.

Freedman, D. S., Brown, J. P., Weir, D. G., and Scott, J. M. (1973). The reproductivity and use of the tritiated folic acid urinary excretion test as a measure of folate absorption in clinical practice: Effect of methotrexate on absorption of folic acid. Journal of Clinical Pathology, 26, 261-267.

Godwin, H. A., and Rosenberg, I. H. (1975). Comparative studies of the intestinal absorption of $\left[{ }^{3} \mathrm{H}\right]$ pteroylmonoglutamate and $\left[{ }^{3} \mathrm{H}\right]$ pteroylheptaglutamate in man. Gastroenterology, 69, 364-373.

Halsted, C. H., Baugh, C. M., and Butterworth, C. E., Jr (1975). Jejunal perfusion of simple and conjugated folates in man. Gastroenterology, 68, 261-269.

Halsted, C. H., Griggs, R. C., and Harris, J. W. (1967). The effect of alcoholism on the absorption of folic acid (H ${ }^{3}$-PGA) evaluated by plasma levels and urine excretion. Journal of Laboratory and Clinical Medicine, 69, 116-131.

Halsted, C. H., Reisenauer, A. M., Romero, J. J., Cantor, D. S., and Ruebner, B. (1977). Jejunal perfusion of simple and conjugated folates in celiac sprue. Journal of Clinical Investigation, 59, 933-940.

Halsted, C. H., Robles, E. A., and Mezey, E. (1971). Decreased jejunal uptake of labeled folic acid $\left({ }^{3} \mathrm{H}-\mathrm{PGA}\right)$ in alcoholic patients: roles of alcohol and nutrition. New England Journal of Medicine, 285, 701-706.

Hepner, G. W., Booth, C. C., Cowan, J., Hoffbrand, A. V., and Mollin, D. L. (1968). Absorption of crystalline folic acid in man. Lancet, 2, 302-306.

Hoffbrand, A. V., Douglas, A. P., Fry, L., and Stewart, J. S. (1970). Malabsorption of dietary folate (pteroylpolyglutamates) in adult coeliac disease and dermatitis herpetiformis. British Medical Journal, 4, 85-89.

Krumdieck, C. L., and Baugh, C. M. (1969). The solid-phase synthesis of polyglutamates of folic acid. Biochemistry, 8 , 1568-1572.

Perry, J., and Chanarin, I. (1968). Absorption and utilization of polyglutamyl forms of folate in man. British Medical Journal, 4, 546-549.

Roe, J. H., and Rice, E. W. (1948). A photometric method 
for the determination of free pentoses in animal tissues. Journal of Biological Chemistry, 173, 507-512.

Rosenberg, I. H. (1976). Absorption and malabsorption of folates. Clinics in Haematology, 5, 589-618.

Rosenberg, I. H., Streiff, R. R., Godwin, H. A., and Castle, W. B. (1969). Absorption of polyglutamic folate: participation of deconjugating enzymes of the intestinal mucosa. New England Journal of Medicine, 280, 985-988.

Shane, B., and Stokstad, E. L. R. (1976). Transport and utilization of methyltetrahydrofolates by lactobacillus casei. Journal of Biological Chemistry, 251, 3405-3410.

Silk, D. B. A., Kumar, P. J., Webb, J. P. W., Lane, A. E., Clark, M. L., and Dawson, A. M. (1975). Ileal function in patients with untreated adult coeliac disease. Gut, 16, 261267.

Steele, R. G. D., and Torrie, J. H. (1960). Principles and Procedures of Statistics, p. 68. McGraw-Hill: New York.

Stewart, J. S., Pollock, D. J., Hoffbrand, A. V., Mollin, D. L., and Booth, C. C. (1967). A study of proximal and distal intestinal structure and absorptive function in idiopathic steatorrhoea. Quarterly Journal of Medicine, 36, 425-444.

Stokes, P. L., Melikian, V., Leeming, R. L., PortmanGraham, H., Blair, J. A., and Cooke, W. T. (1975). Folate metabolism in scurvy. American Journal of Clinical Nutrition, 28, 126-129.

Tamura, T., Buehring, K. U., and Stokstad, E. L. R. (1972). Enzymatic hydrolysis of pteroylpolyglutamates in cabbage. Proceedings of the Society for Experimental Biology and Medicine, 141, 1022-1025.

Tamura, T., and Stokstad, E. L. R. (1973). The availability of food folate in man. British Journal of Haematology, 25, 513-532.

Van de Kamer, J. H., ten Bokkel Huinink, H., and Weyers, H. A. (1949). Rapid method for the determination of fat in feces. Journal of Biological Chemistry, 177, 347-355.

Weir, D. G. (1974). The pathogenesis of folic acid deficiency in man. Irish Journal of Medical Science, 143, 3-20. 